\title{
不確定荷重に対する線形弾性体のロバスト形状最適化問題の解法
}

\author{
下田 昌利 ${ }^{* 1}$, 永野 智大 ${ }^{* 2}$, 新谷 浩平 ${ }^{* 3}$, 伊藤 聡 $^{* 3}$
}

\section{Robust shape optimization method for a linear elastic structure with unknown loadings}

\author{
Masatoshi SHIMODA $^{* 1}$, Tomohiro NAGANO ${ }^{* 2}$, Kohei SHINTANI ${ }^{* 3}$ and Satoshi ITO ${ }^{* 3}$ \\ ${ }^{* 1}$ Toyota Technological Institute \\ 2-12-1 Hisakata, Tempaku-ku, Nagoya-shi, Aichi 468-8511, Japan \\ ${ }^{* 2}$ Graduate School of Engineering, Toyota Technological Institute \\ 2-12-1 Hisakata, Tempaku-ku, Nagoya-shi, Aichi 468-8511, Japan \\ ${ }^{* 3}$ Toyota Motor Corporation \\ 1 Toyota-cho, Toyota-shi, Aichi 471-8571, Japan
}

Received 26 June 2015

\begin{abstract}
In this paper, we propose a robust shape optimization method for a linear elastic structure with unknown loadings. The concept of principal compliance for minimizing the maximal compliance in the unknown loadings is applied to a shape optimization problem of a linear elastic structure. The principal compliance minimization problem is transformed to the equivalent maximization problem of the fundamental eigenvalue, and the problem is formulated as the distributed-parameter shape optimization problem based on the variational method. The derived shape gradient function is applied to the $\mathrm{H}^{1}$ gradient method to determine the optimal shape variation, or the optimal free-form of the linear elastic structure. With this method, the optimal shape can be obtained without shape parameterization, while maintaining the surface smoothness. It is confirmed that the obtained shape has high and uniform stiffness in all directions. We confirm the proposed method is effective for designing the robust shape with high stiffness of a linear elastic structure with unknown loadings.
\end{abstract}

Key words : Robust shape optimization, Loading uncertainties, Principal compliance, $\mathrm{H}^{1}$ gradient method

\section{1. 緒言}

自動車等の機械の構造設計において，構造最適化手法が導入され，その効果が認められている。その適用には 初期構造と材料, 及び境界条件が必要であり, これらが確定している場合には手法に応じて最適寸法, 最適形状, 最適トポロジーが計算される。しかし，構造設計の上流ステージでは，複雑な構造を設計する場合や部品の共有 化を想定する場合など，荷重に関する境界条件が明確に定まらず，不確定性を含む場合があり。その場合，安全 係数を用いることで荷重の不確定性による影響を考慮した構造設計も可能であるが，安易に用いれば過剩な構造 特性を有する冗長構造や荷重増加，コスト増加を招き易い．そのため，荷重の不確定性を理論的に考慮した構造 最適化手法が必要とされており，ロバスト最適化手法として多くの研究が行われている.

荷重方向がある程度想定される場合には，複数の荷重ケースを考慮した多目的，もしくは多制約な最適化手法 の適用が有効であり, 確率を含む複数の荷重パターンの組み合わせから荷重の不確定性を考慮したトポロジー最 適化（Guest and Igusa, 2008）や，荷重変化に対する変位の安定性を目的汎関数に取り入れたコンプライアントメ カニズムに対する多目的トポロジー最適化（Kogiso et al., 2008）が報告されている. 不確定性を確率的手法によ り考慮する方法も報告されており, Chen らは荷重や材料特性の不確定性を考慮したレベルセット法に基づくロバ ストトポロジー最適化手法（Chen et al., 2010）を示している。不確定荷重を表現する荷重集合のうち最悪荷重条

\footnotetext{
No.15-00353 [DOI:10.1299/transjsme.15-00353], J-STAGE Advance Publication date : 12 November, 2015

*1 正員, 豊田工業大学（干468-8511 愛知県名古屋市天白区久方 2-12-1)

*2 豊田工業大学大学院 先端工学科

*3 正員, トヨタ自動車 (株) 車両 CAE 部（干471-8571 愛知県豊田市卜ヨタ町 1)

E-mail of corresponding author: shimoda@toyota-ti.ac.jp
} 
件下での剛性を最大化する手法も考えられ, Ben-Haim らは荷重の不確定性が凸関数の集合で表される場合につい て最悪荷重条件を繰り返し計算により求めており（Ben-Haim and Elishakoff, 1990), de Gournay らは最悪荷重条件 をニュートン法による繰り返し計算により求めレベルセット法に基づく形状及びトポロジー最適化手法（de Gournay et al., 2006) を示している. また, Ben-Tal らはロバスト最適化に関する方法論 (Ben-Tal and Nemirovski, 2002) を示している.

ばらつきを含む評価関数や設計変数に対して平均值や標準偏差を導入する信頼性に基づく最適設計も広く研究 されている. 信頼性最適設計において必要となる信頼性解析では, Rackwitz-Fiessler 法のような繰り返し計算を行 う一次信頼性法（Rackwitz and Fiessler, 1978）が広く用いられている.しかし，そこでは信頼性最適設計が二重ル ープ問題として定式化されるため, 実際の設計問題への適用には膨大な計算コストを要する，その対策として大 別して 2 通りの手法により計算効率の改善が試みられている。その 1 つは safety-factor approach（SFA）(Wu and Wang, 1998）や sequential optimization and reliability assessment（SORA）（Du and Chen, 2004）に代表されるような Decoupled methods で, 信頼性解析から得られる安全係数を用いて信頼性制約を確定制約に変換することで二重ル ープを解消している. もう 1 つは Single-Loop-Single-Vector (SLSV) (Chen et al., 1997)のような single-loop methods で，最適化の繰り返し過程において信頼性制約を等価な確定的制約条件として近似することで二重ループの解消 に成功している．その他，荷重の不確定性を考慮した手法も多く存在する（Jung and Cho, 2004） (Luo et al., 2009)

(Kang and Luo, 2009) (Kang and Luo, 2010).

一方, Cherkaev らは不定荷重に対する剛性最大化問題において主コンプライアンスの概念を提案している. 主 コンプライアンスとは制約を満たす全ての荷重分布ケースの中から最大コンプライアンスを生じる（最悪）荷重 分布に対するコンプライアンスと定義され, 主コンプライアンス最小化のミニマックス問題を固有值問題として 定式化し，ロバスト最適設計問題の解法（(Cherkaev and Cherkaev, 1999）（Cherkaev and Cherkaev, 2008)）を示して いる. 固有值問題一州着させることにより, 繰り返し計算により最悪荷重条件を求める必要がなく, 確率的手法 を用いる方法に比べより厳密な解を得られる. さらに, 竹澤らは Cherkaev らの提案した主コンプライアンスの概 念を基に, 荷重の作用する箇所を限定した問題を対象に解くべき系を縮約し, マトリックス系で定式化しながら, 効率的で実用的な最悪荷重に対するトポロジー最適化の手法（(新居他, 2011）（Takezawa et al., 2011)）を示して いる.

これに対し，ロバスト最適化手法を形状最適化に適用している例は数少ない，室巻らは変位最小化問題が剛性 マトリクスに関する固有值問題に帰着できることを利用し，全体変位や局所変位などを組み合わせた目的汎関数 を用い, そこでは外形と形状は多項式で表現したパラメトリック手法が用いられ，クレーンフックの形状最適化 問題に適用している（室巻他, 2010). 特に, 形状の設計自由度を制限せずに自由境界形状を求め得るノンパラメ トリック形状最適化手法（ノードベース手法ともいわれる）と組み合わせた研究は著者らの知る限りこれまで行 われていない.

ノンパラメトリック形状最適化手法の 1 つに $\mathrm{H}^{1}$ 勾配法（または力法）（畔上, 1994）がある.これは楕円型境界 值問題における分布系の形状最適化問題の一数值解法であり, 領域が自由に変動できる場合の形状勾配関数を用 いて, 領域変動の拘束を満たす速度場を解析するための方法である。この方法は速度場の支配方程式を線形弾性 問題の境界值問題に置き換えて解くために, 有限要素法や境界要素法などが利用できるという点で実用的であり, 支配方程式に現われる形状勾配関数も有限要素法や境界要素法などを利用して解析することが可能である.これ までに平均コンプライアンスを目的関数とする線形弾性問題（畔上，吳，1994）や振動問題（吳，畔上，1995）, 及び変位や応力規定問題（Shimoda et al., 1998）, 温度分布規定問題（片峯他, 1999）等に関する基礎的研究やシ エル構造（Shimoda and Yung, 2014）, 自動車構造への適用（Shimoda et al., 2007）等が研究され, その応用分野が 広まっている.

こうしたこれまでの研究を背景に, 本研究では Cherkaev らの提案した主コンプライアンスの考えを 3 次元線形 弾性体の形状最適化問題へ導入し, $\mathrm{H}^{1}$ 勾配法を利用した不確定荷重に対するロバスト形状最適化問題の新たな解 法を提示することを目的とする. また, 他のロバスト最適化手法等でも一般的に導入されている不確定荷重が満 たすべき制約条件に重み付けを行うことで, 荷重の作用箇所や作用方向に対する荷重の許容值を規定することが でき，より実用的な荷重条件の設定を可能とする，不確定荷重に対する主コンプライアンス最小化問題を剛性テ ンソルの最小固有值の最大化問題に帰着させ, 分布系の最適化問題として定式化し, 感度関数（形状勾配関数） 
を導出する. 得られた形状勾配関数を $\mathrm{H}^{1}$ 勾配法に適用することにより, 滑らかな境界形状を有する高剛性ロバス 卜最適形状を求める. 続く章にて, これらの手続きを順に提示, 説明し, 数值計算結果を通じて手法の有効性を 示寸.

\section{2. 不確定荷重に対するロバスト形状最適化問題}

荷重作用箇所が 3 次元線形弾性体内で固定され，荷重方向が変動する問題を考える. 荷重の大きさは方向によ り重み付けされ, 総荷重は制約されているものとする. 更に, 荷重方向は全方向, もしくは定義した平面内に作 用するものとする. 本論文では荷重作用箇所は規定されているが，その荷重の大きさと方向が不明な状態の荷重 を不確定荷重と定義する．この仮定の下で，全方向，あるいは想定した荷重作用平面内のあらゆる方向からの荷 重に対して, 最大となるコンプライアンスを最小化する 3 次元線形弾性体の最適形状を求める設計問題を考える. この問題の解法のために, 以下のように Cherkaev らの定義した主コンプライアンス (Cherkaev and Cherkaev, 2008) を導入し，本問題を変分法に基づく分布系の形状最適化問題として定式化する.

\section{$2 \cdot 1$ 主コンプライアンスの定義（Cherkaev and Cherkaev, 2008）}

図 1 のように, 領域 $\Omega$ を占め, 境界 $\Gamma$ を有する 3 次元線形弾性体の固定された部分領域 $D_{f}$ に対して, 単位体 積（物体力の場合）もしくは単位面積当たり（表面力の場合）の分布荷重 $\boldsymbol{f}=\left\{f_{i}\right\}_{i=1,2,3}$ が作用するものとする. このとき, $\boldsymbol{v}=\left\{v_{i}\right\}_{i=1,2,3}$ を変位として, 線形弾性体のコンプライアンス $l$ は外力仕事として以下のように定義さ れる. なお, $D_{f}$ は想定する荷重が表面力であるか物体力であるかにより, 部分領域 $\Omega_{f}$ または部分境界 $\Gamma_{f}$ とす る. テンソルの添字表記においては総和規約と空間座標に関する偏微分表記法 $(.)_{, i}=\partial(.) / \partial x_{i}$ を使用する.

$$
l=\int_{D_{f}} f_{i} v_{i} d x, \quad \boldsymbol{v} \in U, \quad D_{f}=\left\{\begin{array}{l}
\Gamma_{f}: \text { for surface forces } \\
\Omega_{f}: \text { for body forces }
\end{array}\right.
$$

ここで, $U=\left\{\boldsymbol{v} \in H^{1}(\Omega)\right\}$ は変位の拘束条件を満たす許容関数空間を表す. 表面力の特別な場合として $\boldsymbol{x}=\hat{\boldsymbol{x}}$ に作 用する集中荷重を考えるとき, $l$ はデル夕関数 $\delta(\cdot)$ を用いて

$$
l=\int_{D_{f}} \delta(\boldsymbol{x}-\hat{\boldsymbol{x}}) f_{i} v_{i} d x
$$

と表される.

主コンプライアンス $l_{p}$ は式（3）により許容荷重集合 $F$ における最大のコンプライアンスと定義される (Cherkaev and Cherkaev, 2008)．また，F は式（4）のような重み付き制約条件を満たす荷重の集合であり，不確 定荷重として想定する荷重の集合と定義される.

$$
\begin{aligned}
& l_{p}=\max _{\boldsymbol{f} \in F}(l) \\
& F=\left\{\boldsymbol{f} \mid \int_{D_{f}} A_{i j}^{-1} f_{i} f_{j} d x=1\right\}
\end{aligned}
$$

ここで， $\left\{A_{i j}\right\}_{i, j=1,2,3}$ は荷重 $\boldsymbol{f}$ の作用箇所と作用（自由度）方向を重み付きで規定する正則な正定值対角マトリクス であり, 荷重が作用している箇所の荷重方向の自由度に対して值を持ち, 荷重が作用しない箇所ではゼロとなる. 例えば， 3 次元問題で全方向への荷重を想定する場合は A11=A22=A33=1 を荷重作用箇所に与える. 荷重方向で 荷重の大きさが異なる場合, 例えば 1 方向の荷重が 2 方向の 2 倍で 3 方向には荷重が作用しない場合は $\mathrm{A} 11=2$, $\mathrm{A} 22=1, \mathrm{~A} 33=0$ となる. 式 (4) には対角マトリクス $A_{i j}$ の逆マトリクスを用いているため, 対角成分の逆数が対応 する荷重方向の重み係数となっている. コンプライアンス $l$ 目的関数, 式 (4) を制約条件とすると, 主コンプ ライアンス $l_{p}$ は $\mu / 2$ をラグランジュ乗数として, 次式のラグランジュ汎関数 $J$ の停留問題の解として求められる. 


$$
J=\int_{D_{f}} f_{i} v_{i} d x-\frac{\mu}{2}\left(\int_{D_{f}} A_{i j}^{-1} f_{i} f_{j} d x-1\right)
$$

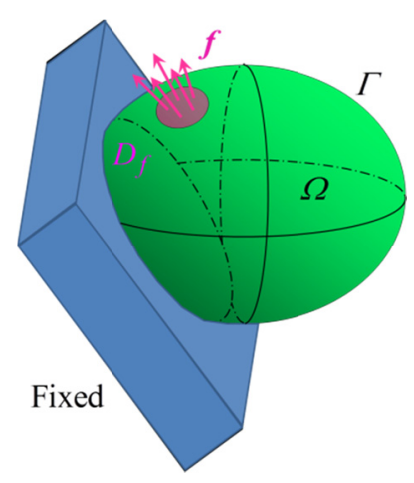

Fig.1 A 3D-linear elastic structure. $\Omega, \Gamma$ denote the bounded domain and boundary of $\Omega$ respectively. $\boldsymbol{f}$ is unknown loadings on (in) $D_{f}$.

$J$ の荷重 $\boldsymbol{f}$ に対する変分をとり, 停留条件を考慮すると,

$$
\begin{aligned}
& \delta J=\int_{D_{f}}\left(v_{i}-\mu A_{i j}^{-1} f_{j}\right) \delta f_{i} d x=0 \\
& f_{i}=\frac{1}{\mu} A_{i j} v_{j}
\end{aligned}
$$

の関係が得られ，これより主コンプライアンス $l_{p}$ は， $\mu$ の最大值 $\mu_{\max }$ を用いて次式で表される.

$$
l_{p}=\max _{\boldsymbol{f} \in F}\left\{\int_{D_{f}} f_{i} v_{i} d x\right\}=\frac{1}{\mu_{\max }} \int_{D_{f}} A_{i j} v_{i} v_{j} d x=\mu_{\max } \int_{D_{f}} A_{i j}^{-1} f_{i} f_{j} d x=\mu_{\max }
$$

一方, 線形弾性体の弾性テンソルを $\left\{C_{i j k l}\right\}_{i, j, k, l=1,2,3}$ とすると, 線形弾性体のひずみエネルギーと外力による仕事 は以下のように関倸付けられる。

$$
a(\boldsymbol{v})=\frac{1}{\mu_{\max }} b(\boldsymbol{v}), \text { または, } \frac{1}{\mu_{\max }}=\frac{a(\boldsymbol{v})}{b(\boldsymbol{v})}
$$

ここで， $a(v)$ は線形弾性体の歪エネルギーの 2 倍を表し， $b(\boldsymbol{v})$ は外力仕事を表す右辺から定数 $1 / \mu_{\max }$ を除いた 部分を表す。

$$
\begin{aligned}
& a(\boldsymbol{v})=\int_{\Omega} C_{i j k l} v_{k, l} v_{i, j} d x \\
& b(\boldsymbol{v})=\int_{D_{f}} A_{i j} v_{i} v_{j} d x
\end{aligned}
$$

$1 / \mu_{\max }$ はv の 2 次形式で表されており, これは Rayleigh-Ritz の定理から $C_{i j k l}$ および $A_{i j}$ から成る系の一般化固有 值 $\lambda^{(r)}(r=1,2, \cdots)$ の最小值 $\lambda^{(1)}$ であることがわかる. この関係は以下のように表される.

$$
l_{p}=\mu_{\max }=\frac{1}{\lambda^{(1)}}
$$

以上の関係から, 主コンプライアンスの最小化問題は系の最小固有值の最大化問題に帰着する.ここで, 式 (9) を満たす変位を固有変位（または主変位）, 式（7）から得られる荷重を固有荷重（または主荷重）と呼ぶことと する. 


\section{$2 \cdot 2$ 主コンプライアンス最小化（最小固有值最大化）問題の定式化}

主コンプライアンス $l_{p}$ の最小化を目的とする形状最適化問題は，仮想仕事の式（または弱形式）を用いながら 式（9）の固有方程式（弱形式）と体積を制約条件に加えることによって, 系の最小固有值 $\lambda^{(1)}$ の最大化（1/ $\lambda^{(1)}$ の最小化）を目的とする分布系の形状最適化問題として以下のように定式化される. なお，目的関数は固有べク トルの正規化（後述の式（26））の容易さを考慮して，1/ $\lambda^{(1)}$ の最小化を等価な $-\lambda^{(1)}$ の最小化に置き換えること とした．また，形状を決める設計変数は $\boldsymbol{V}(\boldsymbol{x})$ で表された設計速度場であり，次節にて定義する.

$\begin{aligned} \text { Given } & \Omega, \hat{M} \\ \text { Find } & \boldsymbol{V} \\ \text { thatminimizes } & -\lambda^{(1)} \\ \text { subject to } & a\left(\boldsymbol{v}^{(1)}, \boldsymbol{w}\right)=\lambda^{(1)} b\left(\boldsymbol{v}^{(1)}, \boldsymbol{w}\right), \quad \forall \boldsymbol{w} \in U, \boldsymbol{v} \in U \\ & M\left(=\int_{\Omega} d V\right) \leq \hat{M}\end{aligned}$

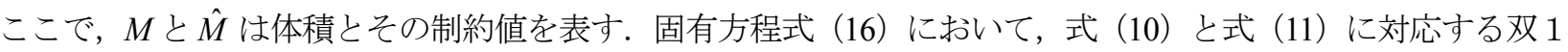
次形式 $a\left(\boldsymbol{v}^{(1)}, \boldsymbol{w}\right)$ と $b\left(\boldsymbol{v}^{(1)}, \boldsymbol{w}\right)$ は主変位 $\boldsymbol{v}^{(1)}$ と随伴変位 $\boldsymbol{w}$ を用いて次のように表される.

$$
\begin{aligned}
& a\left(\boldsymbol{v}^{(1)}, \boldsymbol{w}\right)=\int_{\Omega} C_{i j k l} v_{k, l}^{(1)} w_{i, j} d x \\
& b\left(\boldsymbol{v}^{(1)}, \boldsymbol{w}\right)=\int_{D_{f}} A_{i j} v_{i}^{(1)} w_{j} d x
\end{aligned}
$$

この最小固有值最大化問題には Maxmin 問題に特有の固有值の重根問題が潜在する.この対処方法については 3.2 節で述べる.

\section{$2 \cdot 3$ 領域変動と設計変数}

形状最適化では形状を表す領域を変動させるため, 形状とその変動の定義が必要となる. パラメトリック手法 では一般に境界を多項式やパラメトリック曲面で表し，その係数や定義点の位置や傾き等を変動させ，新たな形 状へ更新する方法が用いられる，一方，ノンパラメトリック手法に基づく本手法では形状は任意に表現し，その 変動は図 2 に示すように領域 $\Omega$, 境界 $\Gamma$ を有する線形弾性体が領域変動により領域 $\Omega_{s}$, 境界 $\Gamma_{s}$ 一と変動するも のとする．領域変動は速度法に基づくと（(Haug et al., 1986）（Sokolowski and Solesio, 1991）(畔上, 1994)), 写像 $T_{S}(\Omega) \in D: X \in \Omega \mapsto \boldsymbol{x} \in \Omega_{S}$ を用いて表される. $D$ は 1 対 1 写像を保証する写像の許容集合, $s$ は写像の媒介変数 $(s \geq 0)$ であり, 変動履歴を表す. また, $s$ に対する $T_{S}$ の導関数 $\boldsymbol{V}(\boldsymbol{x})$ は $X=T_{S}^{-1}(x)$ の関係を用いて次式で定義され る.

$$
\boldsymbol{V}(\boldsymbol{x})=\frac{\partial T_{S}}{\partial s}(\boldsymbol{X}), \quad \boldsymbol{x} \in \Omega_{S}, \boldsymbol{X} \in \Omega
$$

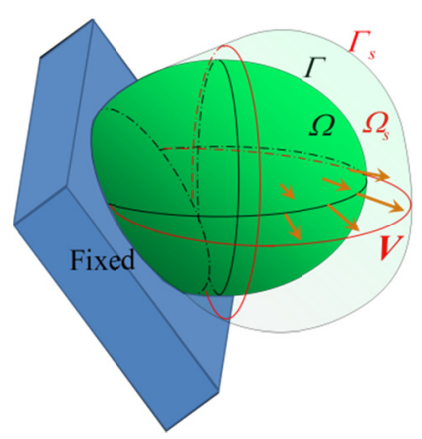

Fig.2 Shape variation by $\boldsymbol{V}(\boldsymbol{x}) . \Omega$ and $\Gamma$ vary to $\Omega_{s}$ and $\Gamma_{s}$ by $\boldsymbol{V}(\boldsymbol{x})$, respectively. 
$\boldsymbol{V}(\boldsymbol{x})$ は設計速度と呼ばれ，領域全体に分布する微小な設計速度場 $\boldsymbol{V}(\boldsymbol{x})$ を用いると， $\Omega$ 内の位置ベクトル $\boldsymbol{X}$ は 次式により $\Omega_{s}$ へ写像される.

$$
\boldsymbol{x}=\boldsymbol{X}+\boldsymbol{V} \Delta s
$$

分布系の形状最適化問題では $\boldsymbol{V}(\boldsymbol{x})$ が設計変数（関数）となり, 目的汎関数を減少させる $\boldsymbol{V}(\boldsymbol{x})$ を求める一手法 として後述する $\mathrm{H}^{1}$ 勾配法は提案されている. 形状最適化問題において, $\boldsymbol{V}(\boldsymbol{x})$ と評価関数の関係は一般的に非線 形であるため, $\boldsymbol{V}(\boldsymbol{x})$ を逐次求めながら形状更新を行う必要がある.

\section{$2 \cdot 4$ ラグランジュ汎関数と形状勾配関数の導出}

2.2 節で定式化された制約付き形状最適化問題に対して，対応するラグランジュ汎関数 $L$ は次式で表される.

$$
L\left(\boldsymbol{v}^{(1)}, \boldsymbol{w}, \Lambda\right)=-\lambda^{(1)}+\lambda^{(1)} b\left(\boldsymbol{v}^{(1)}, \boldsymbol{w}\right)-a\left(\boldsymbol{v}^{(1)}, \boldsymbol{w}\right)+\Lambda(M-\hat{M})
$$

ここで， $\Lambda$ は式（17）の体積制約に対するラグランジュ乗数を表す．また， $\boldsymbol{w}$ は式（16）の固有方程式が弱形 式で表されているため, 式(16)中では変分変位（随伴変位）を表しているが，ラグランジュ汎関数中では強形式 の固有方程式制約条件に対するラグランジュ乗数（関数）を表している．L の領域変動に対する物質導関数 $\dot{L}$ は 物質導関数の公式（Haug et al., 1986）（畔上, 1994）を用いると以下のように求められる.

$$
\dot{L}=-a\left(\boldsymbol{v}^{(1)^{\prime}}, \boldsymbol{w}\right)+\lambda^{(1)} b\left(\boldsymbol{v}^{(1)^{\prime}}, \boldsymbol{w}\right)-a\left(\boldsymbol{v}^{(1)}, \boldsymbol{w}^{\prime}\right)+\lambda^{(1)} b\left(\boldsymbol{v}^{(1)}, \boldsymbol{w}^{\prime}\right)+\dot{\lambda}^{(1)}\left\{b\left(\boldsymbol{v}^{(1)}, \boldsymbol{w}\right)-1\right\}+\Lambda^{\prime}(M-\hat{M})+\langle G \boldsymbol{n}, \boldsymbol{V}\rangle
$$

ラグランジュ汎関数の最適性条件（体積に関しては不等式制約条件を考慮）は次のようになる.

$$
\begin{aligned}
& a\left(\boldsymbol{v}^{(1)}, \boldsymbol{w}^{\prime}\right)=\lambda^{(1)} b\left(\boldsymbol{v}^{(1)}, \boldsymbol{w}^{\prime}\right), \quad \forall \boldsymbol{w}^{\prime} \in U \\
& a\left(\boldsymbol{v}^{(1)^{\prime}}, \boldsymbol{w}\right)=\lambda^{(1)} b\left(\boldsymbol{v}^{(1)^{\prime}}, \boldsymbol{w}\right), \quad \forall \boldsymbol{v}^{(1)^{\prime}} \in U \\
& b\left(\boldsymbol{v}^{(1)}, \boldsymbol{w}\right)=1 \\
& \Lambda(M-\hat{M})=0, \quad \Lambda \geq 0, \quad M-\hat{M} \leq 0
\end{aligned}
$$

式（24）は式（16）と一致する状態変数 $\boldsymbol{v}^{(1)}$ の決定式であり, 式（25）は随伴変数 $\boldsymbol{w}$ の決定式である. 両式か ら $\boldsymbol{v}^{(1)}=\boldsymbol{w}$ の自己随伴関係が成立する. 式（26）は主変位（固有モード）の正規化条件であり, 式（27）は体積 制約に対する最適性条件である.これらの最適性条件が満たされている場合，亡はは次式で表される.

$$
\begin{aligned}
& \dot{L}=\langle G \boldsymbol{n}, \boldsymbol{V}\rangle \\
& \langle G \boldsymbol{n}, \boldsymbol{V}\rangle=\int_{\Gamma} G V_{n} d x=\int_{\Gamma} G \boldsymbol{n} \cdot \boldsymbol{V} d x=\int_{\Gamma} \boldsymbol{G} \cdot \boldsymbol{V} d x \\
& \boldsymbol{G}=\left(-C_{i j k l} v_{k, l}^{(1)} w_{i, j}+\lambda^{(1)} A_{i j} v_{i}^{(1)} w_{j}+\Lambda\right) \boldsymbol{n}=\left(-C_{i j k l} v_{k, l}^{(1)} v_{i, j}+\lambda^{(1)} A_{i j} v_{i}^{(1)} v_{j}+\Lambda\right) \boldsymbol{n}
\end{aligned}
$$

ここで， $\boldsymbol{n}$ は境界 $\Gamma$ に対する外向き単位法線ベクトルを表し， $V_{n}=\boldsymbol{V} \cdot \boldsymbol{n}$ の関係を用いている. $\boldsymbol{G}(=G \boldsymbol{n})$ は形状勾配 関数， $G$ は形状勾配密度関数とよばれる. 導出された形状勾配関数は次章の $\mathrm{H}^{1}$ 勾配法で利用する. 


\section{3. 形状最適化手法と最適化システムの構築}

\section{3・1 $\mathrm{H}^{1}$ 勾配法}

主コンプライアンスを最小化（最小固有值の最大化）させる設計速度場 $\boldsymbol{V}$ は $\mathrm{H}^{1}$ 勾配法（または力法）を用い て求める. $\mathrm{H}^{1}$ 勾配法は畔上によって提案（畔上，1994）されたヒルベルト空間の勾配法に基づくノンパラメトリ ック形状最適化手法であり, 境界の滑らかさを保ちながら目的汎関数を減少させる設計速度場を求める手法であ る. 式（31）は $\boldsymbol{V}$ の支配方程式 (弱形式) を表しており (設計速度解析とよぶ), 最適化対象を擬似弾性体に置 き換え，その設計境界に形状勾配関数を法線方向表面力として与え，そこで得られる変位場を設計速度場として 求める式になっている. 速度場解析の拘束条件は形状設計条件を考慮し, 状態変数解析 (式 (24)) や随伴解析 (式

(25)）とは独立に与える。なお， $C_{\Theta}$ は領域の変動制約を満たす設計速度場 $\boldsymbol{V} の$ 許容関数空間を表す.

$$
a(\boldsymbol{V}, \boldsymbol{y})+\alpha\langle(\boldsymbol{V} \cdot \boldsymbol{n}) \boldsymbol{n}, \boldsymbol{y}\rangle=-\langle G \boldsymbol{n}, \boldsymbol{y}\rangle \quad \forall \boldsymbol{y} \in C_{\Theta}
$$

体積制約は形状勾配関数中のスカラー值 $\Lambda$ を一様分布荷重として設計速度解析で与え，そのときの体積変化よ り決定できる（畔上，呉，1994）（下田他，1994）（Shimoda et al., 1998）.

\section{$3 \cdot 2$ 形状最適化システム}

図 3 に $\mathrm{H}^{1}$ 勾配法を利用して構築したロバスト形状最適化システムの流れを示す. まず，固有值解析（式 (24) ) を行い，形状勾配関数を求める. 固有值解析において，目的汎関数である最小固有值が重根となっている場合に は 3.3 節に示寸形状勾配関数を用いる. 次に, 形状勾配関数を速度場解析に適用寸ることで設計速度場を求める. 得られた設計速度場を用いて形状を更新し, 体積制約を満た寸場合は次の繰り返し（最初の固有值解析）へ進む. 一方，体積制約を満たさない場合には，体積制約を満たすラグランジュ乗数 $\Lambda$ を求め, 設計速度場 $\boldsymbol{V}$ に反映させ た後, 次の繰り返しへ進む. なお, 固有值解析と速度解析には汎用 FEM コードの標準的な固有振動解析と静解 析の機能が利用できる．具体的には式（24）の右辺は固有振動解析の質量マトリックスに代替させ， $A_{i j}$ 中の荷重 作用成分には集中質量を与え, 荷重の作用しないゼロの成分には微小值 $(\approx 0)$ を与える. これにより簡便にロバス 卜最適形状を求めることが可能になる. なお，計算は繰り返し回数を指定，もしくは目的関数の変化量が設定值 以下になった場合に終了させる.

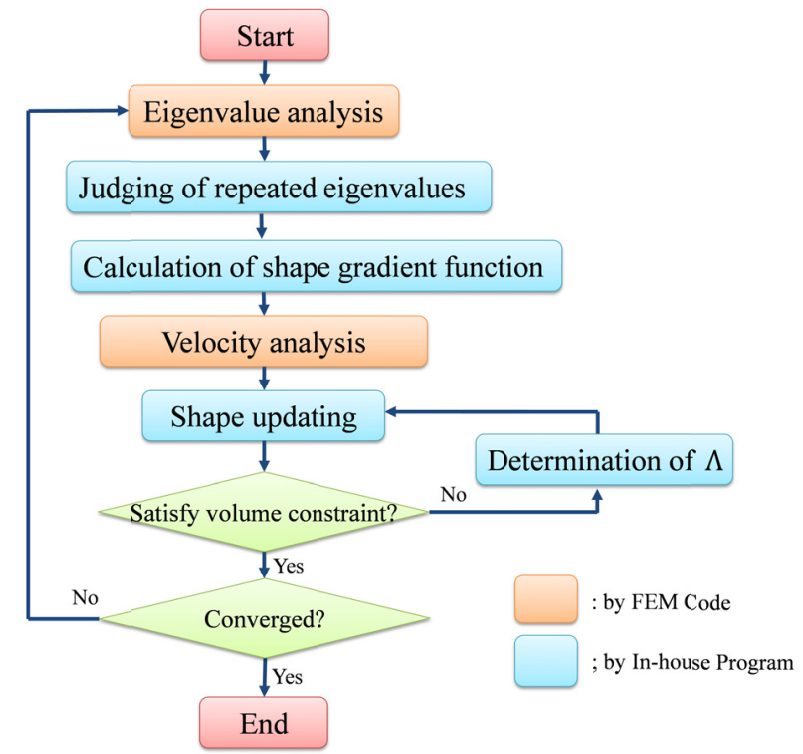

Fig.3 Flowchart of optimization system. First, the eigenvalue analysis is executed, and then the repeated eigenvalues and the shape gradient function are evaluated. Next, the velocity analysis is executed, and then the shape is updated by $\boldsymbol{V}$. If the volume constraint is not satisfied, the shape is re-updated after determining $\Lambda$. If satisfied, the convergence is judged to finish the processes. If not converged, then return to the eigenvalue analysis. 


\section{3 -3 重根問題への対応}

マックスミニ（もしくはミニマックス）問題に潜在する重根問題やそれに伴う最小固有值の入れ替わり現象に 対し, 最適形状一安定的に収束させるため, 本研究では最小固有值が重根と判断された場合, 該当する全ての固 有值を増加させることとした，その場合，ラグランジュ汎関数 $L$ は次式のように表される. なお，重根の数を $N R$ とし, 重根に対応寸る $N R$ 個の固有方程式を制約条件に加えている. また, 重根はある幅 $\left[\lambda^{(1)}, \lambda^{(1)}+\delta_{N R}\right]$ を持た せて判断することとし, 本研究では $\delta_{N R}=0.02 \lambda^{(1)}$ とした.

$$
L\left(\boldsymbol{v}^{(1)}, \cdots, \boldsymbol{v}^{(N R)}, \boldsymbol{w}^{(1)}, \cdots, \boldsymbol{w}^{(N R)}, \Lambda\right)=\sum_{k=1}^{N R}\left\{-\lambda^{(k)}\right\}+\sum_{k=1}^{N R}\left\{\lambda^{(k)} b\left(\boldsymbol{v}^{(k)}, \boldsymbol{w}^{(k)}\right)-a\left(\boldsymbol{v}^{(k)}, \boldsymbol{w}^{(k)}\right)\right\}+\Lambda(M-\hat{M})
$$

ここで， $\lambda^{(k)}$ ，及び $\boldsymbol{v}^{(k)} \in U$ と $\boldsymbol{w}^{(k)} \in U$ はそれぞれ $k$ 番目の重根に対応する固有值 $\left(\lambda^{(k)} \approx \lambda^{(1)}\right)$ とそれに対応す る固有変位と随伴変位を表す。

このラグランジュ汎関数 $L$ に対し, 形状勾配関数 $\boldsymbol{G}$ は 2.4 節と同様の手続きにより次式のように導出される.

$$
\begin{aligned}
& \boldsymbol{G}=\left(G^{(k)}+\Lambda\right) \boldsymbol{n} \\
& G^{(k)}=\sum_{k=1}^{N R}\left(-C_{i j k l} v_{k, l}^{(k)} v_{i, j}^{(k)}+\lambda^{(k)} A_{i j} v_{i}^{(k)} v_{j}^{(k)}\right)
\end{aligned}
$$

導出された形状勾配関数は重根のない場合と同様，式（31）に適用される.

\section{4. 数値計算例}

本手法の有効性を確認するため, 基本的な設計例題へ適用した. 4.1 節では片持ち梁の先端中央に不確定荷重が 作用することを想定した計算結果を示す．このとき，荷重は面内方向に作用する制約を付加した．得られた結果 に対し，目的とする最小固有值の履歴に加え，荷重作用面内の各方向（30 ごと）に対するコンプライアンスの 履歷の評価も行い, 荷重方向に対するロバスト性を確認する. 4.2 節では 4.1 節の数值例における不確定荷重の作 用方向に対して重み付けを行った結果を示す. 4.3 節では片端を固定した厚板モデルに不確定荷重の作用箇所が 2 箇所の場合を想定した結果を示す．また，いずれも体積一定の条件で最適化を行った.

\section{$4 \cdot 1$ 片持ち梁}

図 4(a)のような長方形断面を有する片持ち梁モデル (縦: 60, 横: 100 , 奥行き:200, メッシュ分割数: $6 \times 10 \times 20$ ) において，奥側を完全固定し，手前側自由端の中央部 9 節点を不確定集中荷重の作用箇所とした，更に，荷重は 図に示寸座標系の $X_{2}$ - $X_{3}$ 平面内に作用寸るものとした。 この場合, $A_{i j}$ マトリクスは荷重の作用点に対応する節点 の対角成分は $A_{22}=A_{33}=1$ となり, 節点での荷重成分は式 (4) より $f_{2}^{2}+f_{3}^{2}=1$ の関係を有する. 図 4 (b) は固有 值解析の境界条件を示しており，図４（a）之同様の拘束条件下で，不確定荷重の作用箇所の自由度成分に集中質 量を与えた．戝４（c）は設計速度解析の拘束条件を示しており，長手方向の長さを一定に保つよう荷重点を含む 平面と固定端の表面を滑り拘束し, 荷重の作用箇所は完全拘束した. 図 5 に初期形状での 1 次（図 5 (a)）と 2 次

(図 5 (b)）の固有モードを示す. 1 次は縦方向，2 次は横方向への変位モードである.

得られた最適化形状と A-A からの切断図を図 6 亿示寸. 最適化形状では荷重端側が窄まり, 固定端側が X 字 型に広がっていることがわかる. 1 次と 2 次の目的汎関数である固有值の収束履歴を図 7 に示す. なお, 固有值 の収束を評価するため, 次式の MAC (Modal Assurance Criterion: MAC) 值を用いて初期形状でのモードを追跡し, 履歴を示した. 


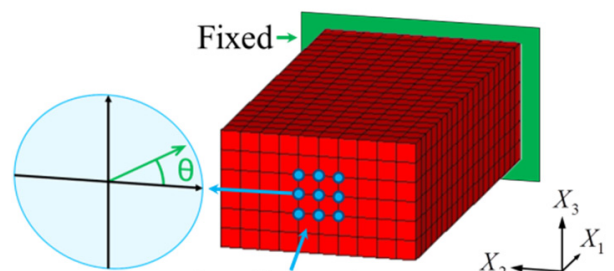

Loading points

(a) Initial shape and unknown loading positions. Unknown loadings are assumed to be applied at 5 nodes on the center of the frontal free surface.

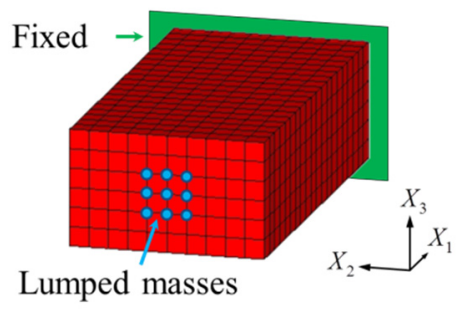

(b) Boundary condition for eigenvalue analysis. One end surface is fixed, and the lumped masses corresponding to $A_{\mathrm{ij}}$ are applied to the unknown loading nodes on the opposite surface.

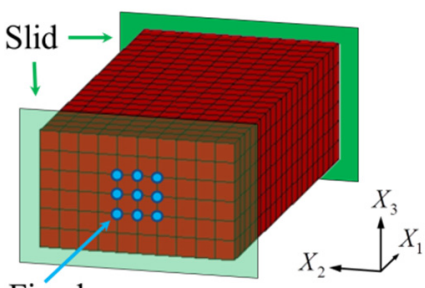

Fixed

(c) Constraint condition for design velocity analysis. Both end boundaries are constrained in the $X_{1}$ direction, and the loading nodes are fixed.

Fig.4 Problem definition of a cantilever beam.

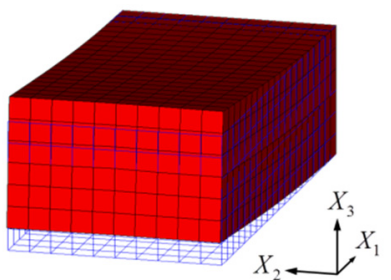

(a) 1st displacement mode of initial shape. Initial shape is shown by wireframe in blue. The shape is tilted in the $X_{3}$ direction.

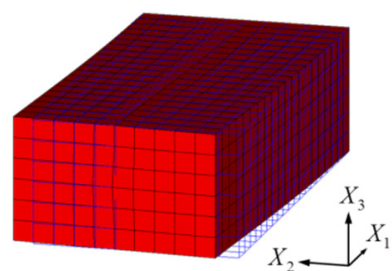

(b) 2nd displacement mode of initial shape. The shape is tilted in the $X_{2}$ direction.

Fig.5 The lowest two displacement modes of the initial shape of a cantilever beam.

$$
\operatorname{MAC}\left(\boldsymbol{\phi}_{0}^{\left(r_{0}\right)}, \boldsymbol{\phi}_{s}^{(r)}\right)=\frac{\left|\boldsymbol{\phi}^{\left(r_{0}\right)}, \boldsymbol{\phi}_{s}^{(r)}\right|^{2}}{\left(\boldsymbol{\phi}_{0}^{\left(r_{0}\right) T} \boldsymbol{\phi}_{0}^{\left(r_{0}\right)}\right)\left(\boldsymbol{\phi}_{s}^{(r) T} \boldsymbol{\phi}_{s}^{(r)}\right)}, \quad r_{0}, r=1,2, \cdots, N R
$$

ここで， $\phi_{0}^{\left(r_{0}\right)}$ は初期の $r_{0}$ 次の固有変位ベクトルを， $\phi_{s}^{(r)}$ は $s$ 回の形状更新後の $r$ 次の固有ベクトルを表す. また, 上付き添え字 $T$ はベクトルの転置を表す．MAC 值が最大となるモード $\left(\phi_{0}^{\left(r_{0}\right)}\right.$ と $\phi_{s}^{(r)}$ が一致する場合は 1$)$ を当該 モードとして選択した．図 7 より，直接の目的汎関数である最小固有值は 25 回目の形状更新で重根となり，その 後は重根を保ちながら安定して増加し, 最終的には初期值の約 4.9 倍で収束していることがわかる. 更に, 得ら れた形状のロバスト性，すなわち設定した $X_{2}-X_{3}$ 平面内のあらゆる方向に対してコンプライアンスの変動の少な い形状になっているかを確認寸るため, 周方向 $\theta=30^{\circ}$ 毎（図 4(a)中）に $f_{2}^{2}+f_{3}^{2}=1$ の関係を満たす節点荷重 (許 容荷重）を与え，コンプライアンスの評価を行った。 なお， $\theta$ は $X_{2}$ 軸の負方向から反時計回りを正とした（以降 も同様)．各方向に対するコンプライアンスの収束履歴を図 8 (a) に示す. 各繰り返しでの最大值を示す方向の コンプライアンスが主コンプライアンスである。初期形状で低剛性であった $\theta=90^{\circ} ， 270^{\circ}$ （縦方向）の（主） コンプライアンスが減少し，相対的に高剛性であった $0^{\circ} ， 180^{\circ}$ （横方向）のコンプライアンスは 25 回まで増 加し，その後は全ての方向の值がほぼ一致した状態で減少していることがわかる．すなわち，荷重方向に対する 剛性のばらつきが減少し，ロバス卜性を有した高剛性形状へ向っていることが確認される．最終的に主コンプラ イアンスは初期形状に比較して約 80\%減少していることがわかる. 各方向に対する初期形状と最適化形状でのコ ンプライアンスの比較（極座標表示）を図 8 (b) に示す. なお, 荷重方向を偏角 $\theta$ にり, その方向の荷重に対 するコンプライアンスを半径で表しており，グラフが円形状に近づくほどロバスト性に優れた形状となる．初期 形状では縦方向に細長く, 荷重方向の変化に対して方向性を有しているが，最適化形状では円となり，半径が小 さくなっていることから高剛性化がなされていることがこの結果からも確認される. これらの結果から, 本手法 によりロバスト性に優れた高剛性形状が得られることが確認される. 

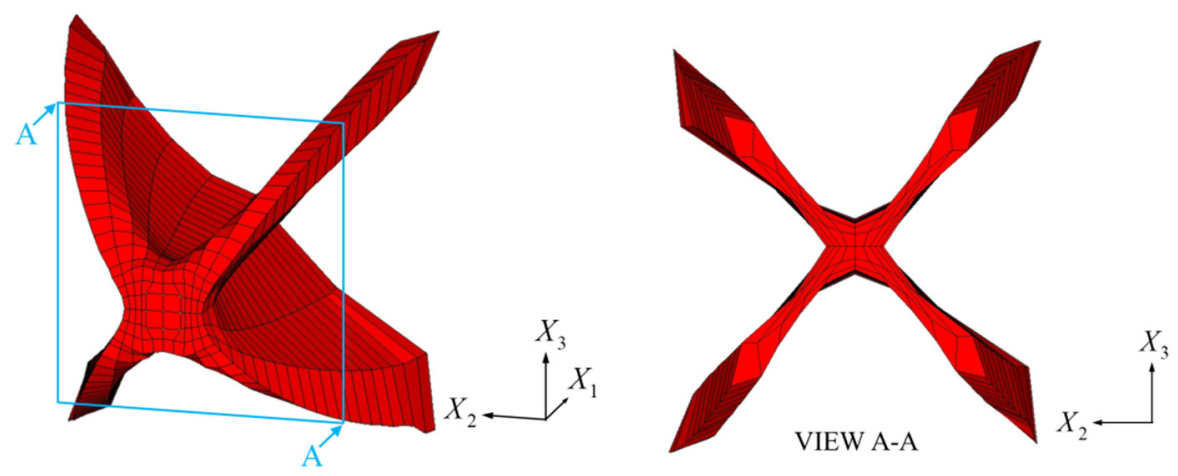

Fig.6 The optimized shape and the cutting view from A-A of a cantilever beam. The domain near the fixed end largely expands, while the domain near the loading points shrinks. The shape becomes X-shaped cross-section.

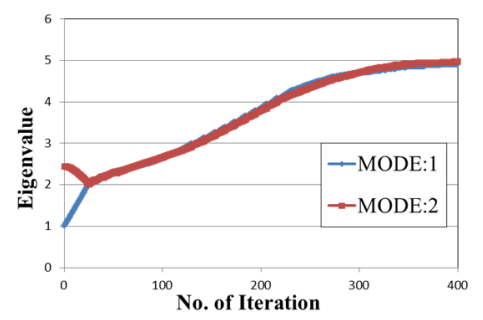

Fig.7 Iteration histories of the $1^{\text {st }}$ (blue) and $2^{\text {nd }}$ (red) eigenvalues of a cantilever beam. The eigenvalues are normalized to the 1 st eigenvalue of the initial shape. The 1st eigenvalue becomes repeated eigenvalue at 25 iteration and is maximized to approximately 4.9 times the initial value.

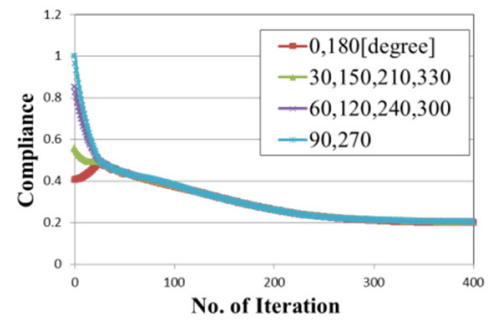

(a) The convergence histories of the evaluated compliances at every 30 degree in the circumferential direction. The principal compliance is reduced by approximately $80 \%$.

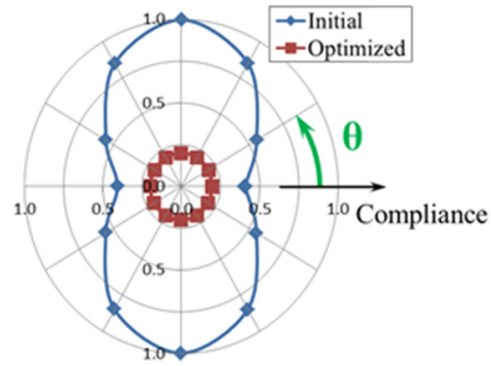

(b) Comparison of compliance distributions in the polar coordinate between the initial and the optimized shapes. The compliances are compared at every 30 degree in the circumferential direction. The optimized shape has low and uniform compliances along the loading directions.

Fig.8 Comparisons of convergence histories and distributions of the compliances in the circumferential direction of a cantilever beam.

\section{$4 \cdot 2$ 荷重方向の重み付け}

次に, 4.1 節の例題と不確定荷重の作用箇所は同様とし，作用方向に対して重み付けした計算例を示す．重みは 横 $\left(X_{2}\right)$ 方向荷重の許容值が縦 $\left(X_{3}\right)$ 方向に対して 2 倍になることを想定し， $A_{i j}$ マトリクスは荷重の作用点に対 応する節点の対角成分が $A_{22}=2, A_{33}=1$ とした. 節点での荷重成分は式 (4) より $0.5 f_{2}^{2}+f_{3}^{2}=1$ の関係となる. そ の他の境界条件や結果の評価方法は 4.1 節と同様とした. 初期の固有モードは 4.1 節の図 5 と同様に 1 次モードが 縦方向, 2 次モードが横方向の変位モードであった.

切断図を含む得られた最適化形状を図 9 に示す．得られた形状は荷重端側が収縮し，固定端側が $\mathrm{H}$ 字型に拡が っており，4.1節での最適化形状に比較して, 重み付けした横 $\left(X_{2}\right)$ 方向荷重に対して岡川い形状となっていること がわかる. 1 次と 2 次固有值の収束履歴を図 10 に示すが, 6 回で重根となり, その後は安定して増加している. これは, 重み付けにより $x_{2}$ 方向に対する荷重の許容值が 2 倍となったため, 対応するコンプライアンスも倍増 し, その逆数を取る固有值が半減したためである.このことは 4.1 節で 1 次固有值の約 2.4 であった 2 次固有值が, 本節ではその $1 / 2$ となる約 1.2 倍となっていることからも確認できる. グラフから最小固有值は最終的に初期形 状の值の約 3.4 倍になっていることがわかる. 

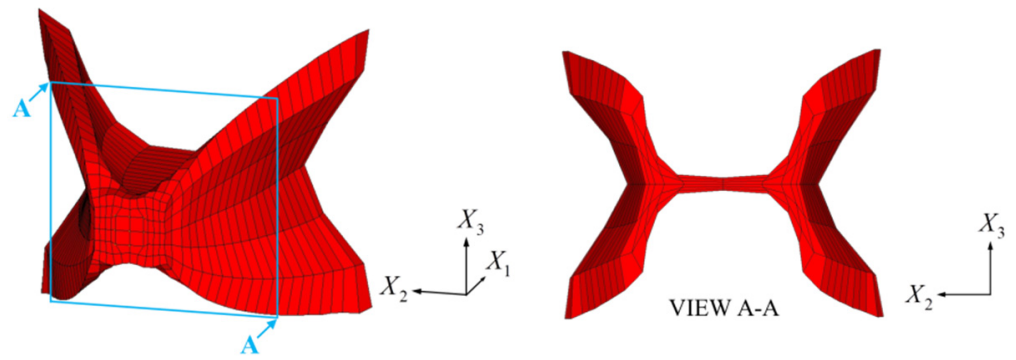

Fig.9 The optimized shape and the cutting view from A-A for the weighted unknown loadings. The domain near the fixed end expands, while the other domain shrinks toward the loading area. The shape has H-shaped cross-section.

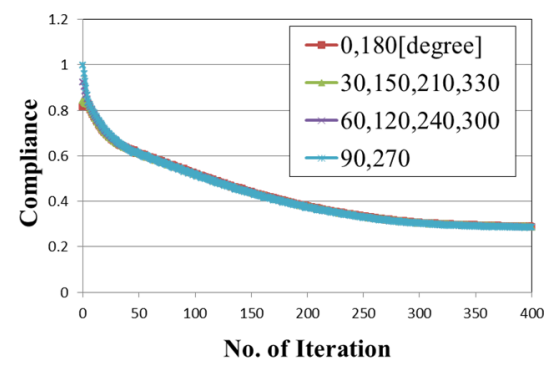

(a) The convergence histories of the evaluated compliances at every 30 degree in the circumferential direction. The principal compliance is reduced by approximately $75 \%$.

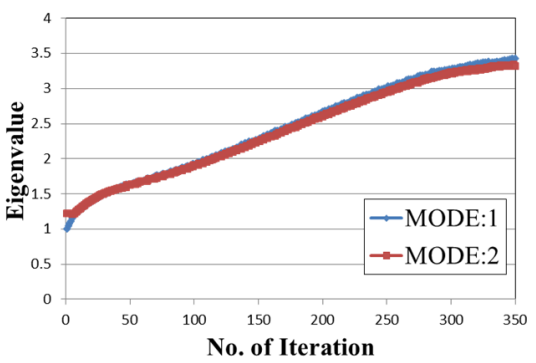

Fig.10 Iteration histories of the $1^{\text {st }}$ (blue) and $2^{\text {nd }}$ (red) eigenvalues for the weighted unknown loadings. The eigenvalues are normalized to the 1 st eigenvalue of the initial shape. The 1st eigenvalue becomes repeated eigenvalue at 6 iteration, and is maximized to approximately 3.4 times the initial value.

Fig.11 Comparisons of convergence histories and distributions of the compliances in the circumferential direction for the weighted unknown loadings.

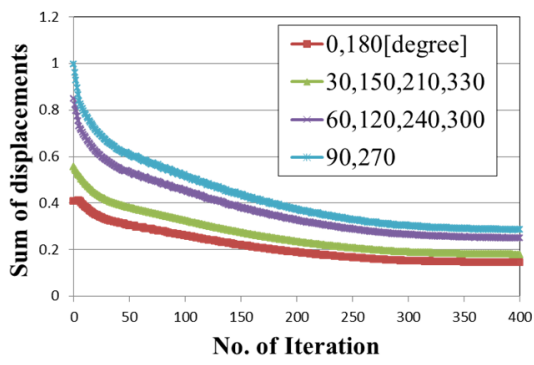

(a) The convergence history of the evaluated sum of displacements at every 30 degree in the circumferential direction. The displacement in $X_{2}$ direction becomes equal to 2 times that of $X_{3}$ direction, and both displacements decreases with this relation.

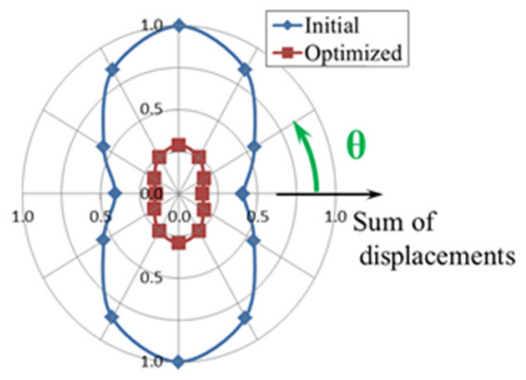

(b) Comparison of the sum of the displacements distributions in the polar coordinate between the initial and the optimized shapes. The sum of the displacements at the loading points are compared at every 30 degree in the circumferential direction. The optimized shape has higher stiffness than the initial shape in all direction. The sum of the displacements at $\theta=0^{\circ}$ of the optimized is half as much as that at $\theta=90^{\circ}$.

Fig.12 Comparisons of iteration histories and distributions of the displacements at the unknown loading points in the circumferential direction for the weighted unknown loadings. 
また，図 $11 （ \mathrm{a})$ （b）には周方向 $30^{\circ}$ 毎に $0.5 f_{2}^{2}+f_{3}^{2}=1$ の関係を満たす節点荷重を与え，コンプライアンスを評 価した結果を示寸（ (a)は収束履歴, (b)は初期形状と最適化形状の比較)。また, 図 12 (a) (b) にはコンプライ アンスから荷重を除した負荷点変位の和の評価結果を示寸. 図 11 （a）（b）の両図から，重根になったとき，ほ ぼロバスト形状となり，その後はロバスト性を保ちながら高剛性化されていることがわかる．最適化形状の主コ ンプライアンスは初期から約 70\%減少している. 図 12 (a) (b) からは, 重根となった 6 回目の形状更新から横 方向 $\left(0,180^{\circ}\right)$ の変位が縦方向 $\left(90,270^{\circ}\right)$ の約 $1 / 2$ 倍となり, 以降はその比を保ちながら高剛性化に向かって いることが確認される.これらの結果から, 荷重方向によって荷重の大きさが重みつけされるような場合に対し ても，提示手法が有効に機能することが確認された.

\section{$4 \cdot 3$ 離れた 2 箇所に不確定負荷を受ける片持ち厚板モデル}

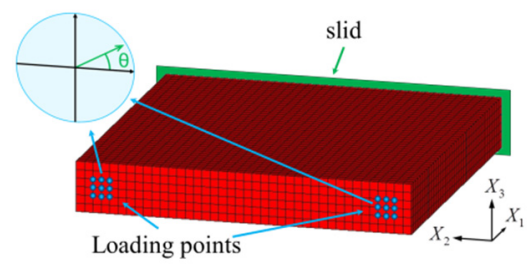

(a) Initial shape and unknown loading points. Unknown loadings are assumed to be applied at 5 nodes in two areas near right and left edges on the frontal free surface.

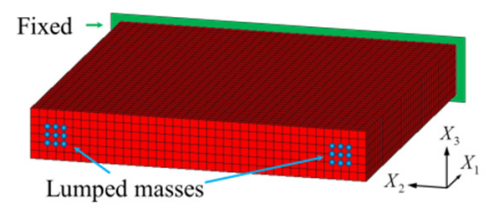

(b) Boundary condition for eigenvalue analysis. One end surface is fixed, and the lumped masses corresponding to $A_{\mathrm{ij}}$ are applied to the unknown loading nodes on the opposite surface.

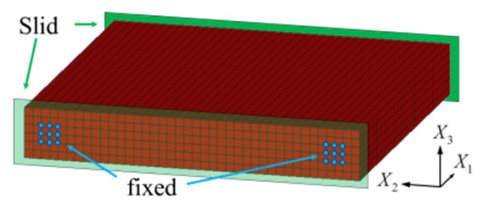

(c) Constraint condition for design velocity analysis. Both end boundaries are constrained in the $X_{1}$ direction, and the loading area is fixed.

Fig.13 Problem definition of a cantilever plate model with unknown loadings in the separate areas.

図 13(a)に示すような正方厚板モデル（縦 : 400, 横 : 400, 厚さ : 60, メッシュ分割数 : 40×40×6）において, 一面を完全固定し，対面の左右 2 箇所（各 5 節点）を不確定集中荷重の作用箇所とした. 更に，荷重は前の問題と 同様，図に示寸座標系の $X_{2}-X_{3}$ 平面内に作用するものとした， $A_{i j}$ マトリクスは荷重の作用点に対応する節点の対角 成分に $A_{22}=A_{33}=1$ を与え, 節点での荷重成分は $f_{2}^{2}+f_{3}^{2}=1$ の関係を有する. 図 13 (b) は固有值解析の境界条件を 示しており, 図 13 (a) と同様の拘束条件下で, 不確定荷重の作用箇所の自由度成分に集中質量を与えた. 図 13 (c) は設計速度解析の拘束条件を示しており，長手方向の長さを一定に保つよう荷重点を含む平面と固定端の表面を滑 り拘束し, 荷重の作用箇所は完全拘束した. 図 14(a)から(c)に, 初期形状での 1 次から 3 次の固有モードを示す. 1 次は縦方向， 2 次は捩れ， 3 次は横方向への変位モードである.

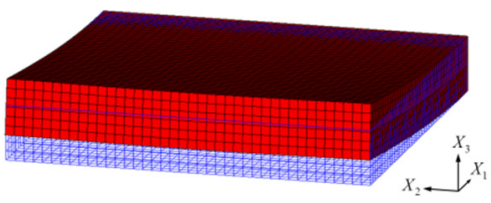

(a) 1st displacement mode of initial shape. Initial shape is showed by wireframe of blue. The shape is tilted in the $X_{3}$ direction.

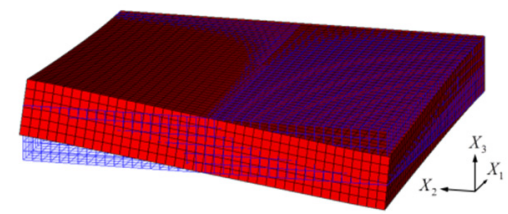

(b) 2nd displacement mode of initial shape. The shape twist in the $X_{2} X_{3}$ plane.

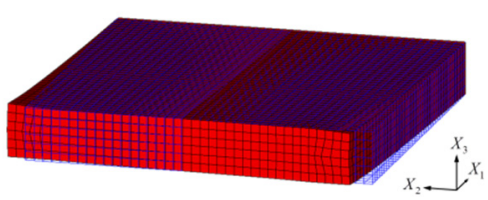

(c) 3rd displacement mode of initial shape. The shape is tilted in the $X_{2}$ direction.

Fig.14 The lowest three displacement modes of the initial shape a cantilever plate with unknown loadings in the separate areas.

図 15 に示寸最適化形状では, 両荷重作用箇所からリブのような形状が形成され, 断面はH型になっている. 図 16 に示寸固有值の収束履歴から, 71 回で 2 次固有值と重根に, 121 回で 3 次モードとも重根となり, その後は安 
定的に増加し, 最小固有值は最終的に初期值の約 14.1 倍となっていることがわかる. コンプライアンスについて, 図 17 (a) の収束履歴から, 低剛性であった縦方向（90,270 ）や $60,120^{\circ}$ 方向の補剛によりロバス卜性が改善 され，以降はその一様コンプライアンスを保ちながらさらに高剛性化されていることが確認される. 図 17 (b) に示寸初期と最適化形状のコンプライアンス分布の比較から, 初期形状では縦長の分布のグラフが, 最適化形状 では半径の小さい円となっている．初期形状において比較的高剛性であった横方向は最適化により約 1.3 倍コン プライアンスが増加し, 一方, 縦方向のコンプライアンスは大きく減少している. 結果として, 主コンプライア ンスは初期に比べ, 約 93\%減少している.これらの結果から, 荷重の作用箇所が 2 箇所となった場合でも形状の ロバスト性を高めながら, 高剛性化がなされていることが確認される.
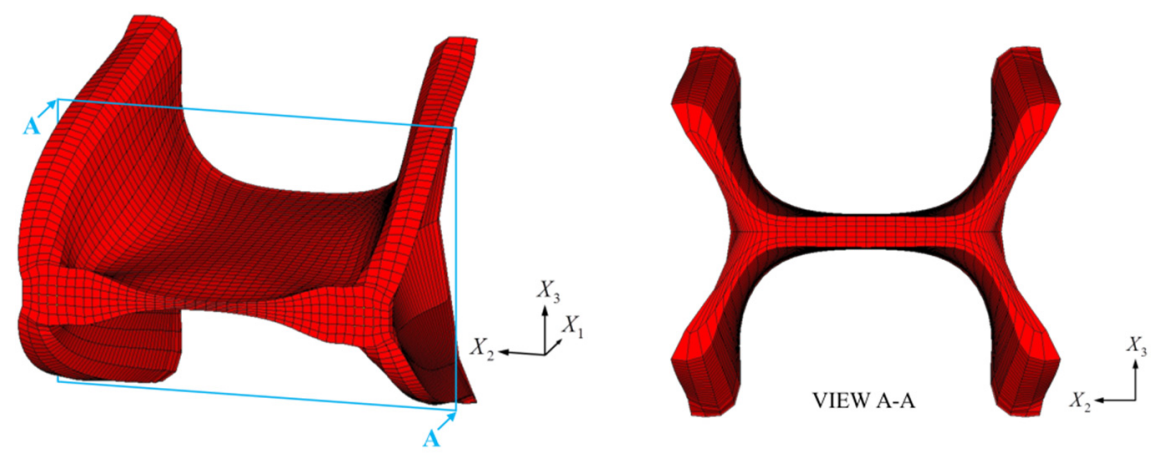

Fig.15 The optimized shape and definition of the cross-sectional view of a cantilever plate with unknown loadings in the separate areas. Two ribs are created near both loading areas and the cross-section becomes H-shaped.

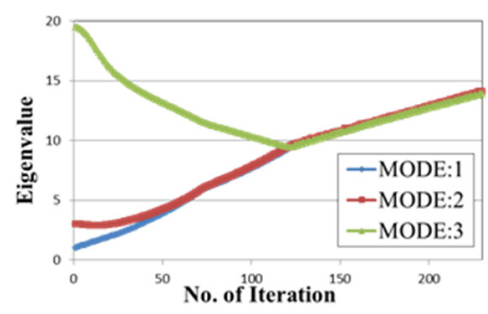

Fig.16 Iteration histories of the $1^{\text {st }}$ (blue), $2^{\text {nd }}$ (red) and $3^{\text {rd }}$ (green) eigenvalues of a cantilever plate with unknown loadings in the separate areas. The eigenvalues are normalized to the 1 st eigenvalue of the initial shape. The 1st eigenvalue becomes repeated eigenvalue with 2 nd eigenvalue at 71 iteration, and with 3rd eigenvalue at the 121 iteration. Finally, it is maximized to approximately 14.1 times the initial value.

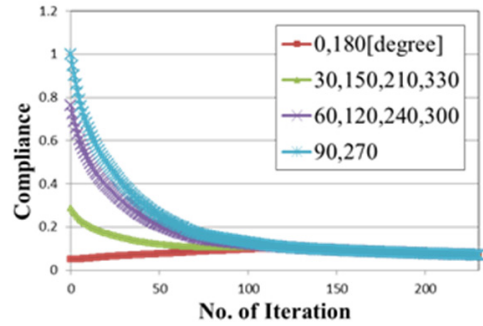

(a) The convergence histories of the evaluated compliances at every 30 degree in the circumferential direction. The principal compliance is reduced by approximately $93 \%$.

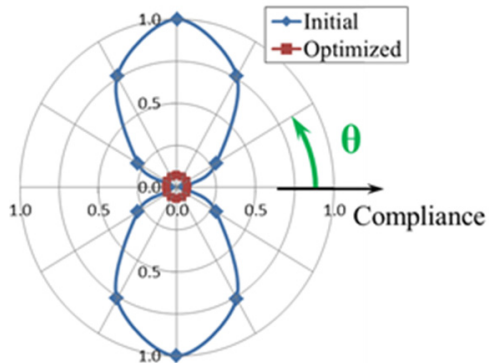

(b) Comparison of compliance distributions in the polar coordinate between the initial and the optimized shapes. The compliances are compared at every 30 degree in the circumferential direction. The optimized shape has low and uniform compliances along the loading directions.

Fig.17 Comparisons of convergence histories and distributions of the compliances in the circumferential direction of a cantilever plate with unknown loadings in the separate areas.

\section{5. 結 言}

本研究では Cherkaev らの提案した主コンプライアンスの概念を 3 次元連続体の形状最適化問題へ適用し, 不確 定荷重に対するロバスト形状最適化問題の解法を提示した。不確定荷重に対する主コンプライアンス最小化問題 が系の最小固有値の最大化問題に帰着することを利用し，主コンプライアンス最小化を目的とする形状最適化問 題を分布系で定式化し, 形状勾配関数を導出した. 形状勾配関数の具体的な数值計算を汎用 FEM コードの実固 有值解析を利用して簡便に行う方法も示した. 得られた形状勾配関数を $\mathrm{H}^{1}$ 勾配法に適用することにより, 滑らか 
な境界形状を有する高岡性ロバスト最適形状を求めることを可能にした．また，本問題のような Minimax（又は Maxmin）問題に潜在する重根問題に対応する方法と荷重方向によって荷重に重夕付けする方法も示した. 提示し た一連の解法を設計例題へ適用し，その有効性を確認した。

\author{
謝 辞 \\ 本研究の一部には文部科学省私立大学戦略的研究基盤形成支援事業「難環境作業スマート機械技術の開発」の \\ 補助金を用いました．記して厚く感謝の意を表します．
}

\title{
文献
}

畔上秀幸, 領域最適化問題の一解法，日本機械学会論文集 A 編, Vol. 60, No. 574 (1994), pp. 1479-1486.

畔上秀幸, 呉志強, 線形弾性問題における領域最適化解析 (力法によるアプローチ), 日本機械学会論文集 $\mathrm{A}$ 編, Vol.60, No.578 (1994), pp. 2312-2318.

Ben-Haim, Y. and Elishakoff, I., Convex models of uncertainty in applied mechanics, Elsevier, Amsterdam (1990).

Ben-Tal, A. and Nemirovski, A., Robust optimization - methodology and applications, Mathematical Programming, B92 (2002), pp. 453-480.

Chen, S., Chen, W. and Lee, S., Level set based robust shape and topology optimization under random field uncertainties, Structural and Multidisciplinary Optimization vol.41, No.4 (2010), pp. 507-524.

Chen, X., Hasselman, T. K. and Neill, D. J., Reliability based structural design optimization for practical applications, Proceedings of 38th AIAA/ASME/ASCE/AHS/ASC Structures, Structural Dynamics and Materials Conference, Vol. 4, (1997), pp. 2724-2732.

Cherkaev, A. and Cherkaev, E., Optimal design for uncertain loading condition, Series on Advances in Mathematics for Applied Sciences, Vol. 50 (1999), pp.193-213.

Cherkaev, E. and Cherkaev, A., Minimax optimization problem of structural design, Computers \& Structures vol. 86, No. 13 (2008), pp. 1426-1435.

De Gournay, F., Allaire, G. and Jouve, F., Shape and topology optimization of the robust compliance via the level set method, ESAIM: Control, Optimisation and Calculus of Variations, Vol.14, No.1 (2006), pp. 43-70.

$\mathrm{Du}, \mathrm{X}$. and Chen, W., Sequential optimization and reliability assessment method for efficient probabilistic design, Journal of Mechanical Design, Vol. 126, No. 2 (2004), pp. 225-233.7.

Guest, J. and Igusa, T., Structural optimization under uncertain loads and nodal locations, Computer Methods in Applied Mechanics and Engineering Vol. 198, No. 1 (2008), pp. 116-124.

Haug, E. J., Choi, K. K. and Komkov, V., Design sensitivity analysis of structural systems, Vol.177, Academic Press, Orlando (1986).

Jung, H. S. and Cho, S., Reliability-based topology optimization of geometrically nonlinear structures with loading and material uncertainties, Finite elements in analysis and design, Vol. 41, No. 3 (2004), pp. 311-331.

Kang, Z. and Luo, Y., Non-probabilistic reliability-based topology optimization of geometrically nonlinear structures using convex models, Computer Methods in Applied Mechanics and Engineering, Vol. 198, No.41 (2009), pp.3228 - 3238.

Kang, Z. and Luo, Y., Reliability-based structural optimization with probability and convex set hybrid models, Structural and Multidisciplinary Optimization, Vol. 42, No. 1 (2010), pp. 89-102.

片峯英次, 畔上秀幸, 小嶋雅美，定常熱伝導場における境界形状決定，日本機械学会論文集 B 編, Vol.65, No.629 (1999), pp. 275-281.

Kogiso, N., Ahn, W., Nishiwaki, S., Izui, K. and Yoshimura, M., Robust topology optimization for compliant mechanisms considering uncertainty of applied loads, Journal of Advanced Mechanical Design, Systems, and Manufacturing, Vol. 2, No. 1 (2008), pp. 96-107.

Luo, Y., Kang, Z., Luo, Z. and Li A., Continuum topology optimization with nonprobabilistic reliability constraints based on multi-ellipsoid convex model, Structural and Multidisciplinary Optimization Vol.39, No.3 (2009), pp. 297-310.

室巻孝郎, 花原和之, 多田幸生, 西村拓真, 黒田恵之, 福井忠久, 不特定荷重を考慮した構造物の最適形状設計: 多項式系による形状表現とクレーンフック設計一の適用，日本機械学會論文集 A 編, Vol.76, No. 770 (2010), pp. $1241-1246$. 
新居悟, 竹澤晃弘, 北村充, 小木曽望, 縮約された線形システムを用いた不確定荷重に対するロバストトポロジー 最適化，日本機械学会論文集 A 編，Vol. 77, No. 775 (2011), pp. 90-100.

Rackwitz, R. and Fiessler, B., Structural reliability under combined random load sequences, Computers \& Structures, Vol.9 (1978), pp. 489-494.

Shimoda, M., Azegami, H. and Sakurai, T., Non-parametric shape optimization method for rigidity design of automotive sheet metal structures, SAE 2006 Transactions, Journal of Passenger Cars-Mechanical Systems, No. 2006-01-0584 (2007), pp.483-492.

Shimoda, M., Azegami, H. and Sakurai, T., Traction method approach to optimal shape design problems, SAE 1997 Transactions, Journal of Passenger Cars, Section 6, Vol.106 (1998), pp. 2355-2365.

下田昌利, 吳志強, 畔上秀幸, 桜井俊明, 汎用 FEM コードを利用した領域最適化問題の数值解法（力法によるア プローチ)，日本機械学会論文集 A 編, Vol. 60, No. 578 (1994), pp. 250-257.

Shimoda, M. and Yang, L., A non-parametric free-form optimization method for shell structures, Structural and Multidisciplinary Optimization, Vol. 50 (2014), pp. 409-423.

Sokolowski, J. and Zolesio, J. P., Introduction to shape optimization, shape sensitivity analysis, Springer-Verlag, New York (1991).

Takezawa, A., Nii, S., Kitamura, M. and Kogiso, N., Topology optimization for worst load conditions based on the eigenvalue analysis of an aggregated linear system, Computer Methods in Applied Mechanics and Engineering, Vol. 200 (2011), pp. $2268-2281$.

呉志強, 畔上秀幸, 固有振動問題における領域最適化解析（力法によるアプローチ），日本機械学会論文集 C 編, Vol. 61, No. 583 (1995), pp. 930-937.

$\mathrm{Wu}, \mathrm{Y}$. T. and Wang, W., Efficient probabilistic design by converting reliability constraints to approximately equivalent deterministic constraints, Journal of Intergrated Design and Process Sciences, Vol. 2, No. 4 (1998), pp. 13-21.

\section{References}

Azegami, H., Solution to domain optimization problems, Transactions of the Japan Society of Mechanical Engineers, Series A, Vol. 60, No. 574 (1994), pp. 1479-1486 (in Japanese).

Azegami, H. and Wu, Z. C., Domain optimization analysis in linear elastic problems (approach using traction method), Transactions of the Japan Society of Mechanical Engineers, Series A, Vol. 60, No. 578 (1994), pp.2312-2318 (in Japanese).

Ben-Haim, Y. and Elishakoff, I., Convex models of uncertainty in applied mechanics, Elsevier, Amsterdam (1990).

Ben-Tal, A. and Nemirovski, A., Robust optimization - methodology and applications, Mathematical Programming, B92 (2002), pp. 453-480.

Chen, S., Chen, W. and Lee, S., Level set based robust shape and topology optimization under random field uncertainties, Structural and Multidisciplinary Optimization vol.41, No.4 (2010), pp. 507-524.

Chen, X., Hasselman, T. K. and Neill, D. J., Reliability based structural design optimization for practical applications, Proceedings of 38th AIAA/ASME/ASCE/AHS/ASC Structures, Structural Dynamics and Materials Conference, Vol. 4 (1997), pp. 2724-2732.

Cherkaev, A. and Cherkaev, E., Optimal design for uncertain loading condition, Series on Advances in Mathematics for Applied Sciences, Vol. 50 (1999), pp.193-213.

Cherkaev, E. and Cherkaev, A., Minimax optimization problem of structural design, Computers \& Structures vol. 86, No. 13 (2008), pp. 1426-1435.

De Gournay, F., Allaire, G. and Jouve, F., Shape and topology optimization of the robust ompliance via the level set method, ESAIM: Control, Optimisation and Calculus of Variations,Vol.14, No.1 (2006), pp. 43-70.

$\mathrm{Du}, \mathrm{X}$. and Chen, W., Sequential optimization and reliability assessment method for efficient probabilistic design, Journal of Mechanical Design, Vol. 126, No. 2 (2004), pp. 225-233.7.

Guest, J. and Igusa, T., Structural optimization under uncertain loads and nodal locations, Computer Methods in Applied Mechanics and Engineering Vol. 198, No. 1 (2008), pp. 116-124.

Haug, E. J., Choi, K. K. and Komkov, V., Design sensitivity analysis of structural systems, Vol.177, Academic Press, Orlando (1986). 
Jung, H. S. and Cho, S., Reliability-based topology optimization of geometrically nonlinear structures with loading and material uncertainties, Finite elements in analysis and design, Vol. 41, No. 3 (2004), pp. 311-331.

Kang, Z. and Luo, Y., Non-probabilistic reliability-based topology optimization of geometrically nonlinear structures using convex models, Computer Methods in Applied Mechanics and Engineering, Vol. 198, No.41 (2009), pp.3228-3238.

Kang, Z. and Luo, Y., Reliability-based structural optimization with probability and convex set hybrid models, Structural and Multidisciplinary Optimization, Vol. 42, No. 1 (2010), pp. 89-102.

Katamine, E., Azegami, H. and Kojima, M., Boundary shape determination on steady-state heat conduction field, Transactions of the Japan Society of Mechanical Engineers, Series B, Vol. 65, No. 629 (1999), pp. 275 - 281 (in Japanese).

Kogiso, N., Ahn, W., Nishiwaki, S., Izui, K. and Yoshimura, M., Robust topology optimization for compliant mechanisms considering uncertainty of applied loads, Journal of Advanced Mechanical Design, Systems, and Manufacturing, Vol. 2, No. 1 (2008), pp. 96-107.

Luo, Y., Kang, Z., Luo, Z. and Li A., Continuum topology optimization with nonprobabilistic reliability constraints based on multi-ellipsoid convex model, Structural and Multidisciplinary Optimization Vol.39, No.3 (2009), pp. 297-310.

Muromaki, T., Hanawara, K., Tada, Y., Nishimura, T., Kuroda, S. and Fukui, T., Structural shape design considering unspecified load conditions (Polynomial shape representation and application to crane-hook design), Transactions of the Japan Society of Mechanical Engineers, Series A, Vol. 76, No. 770 (2010), pp.1241 - 1246 (in Japanese).

Nii, S., Takezawa, A., Kitamura, M. and Kogiso, M., Robust topology optimization based on an aggregated linear system and eigenvalue analysis, Transactions of the Japan Society of Mechanical Engineers, Series A, Vol. 77, No. 775 (2011), pp. 90-100 (in Japanese).

Rackwitz, R. and Fiessler, B., Structural reliability under combined random load sequences, Computers \& Structures, Vol.9 (1978), pp. 489-494.

Shimoda, M., Azegami, H. and Sakurai, T., Non-parametric shape optimization method for rigidity design of automotive sheet metal structures, SAE 2006 Transactions, Journal of Passenger Cars-Mechanical Systems, No. 2006-01-0584 (2007), pp.483-492.

Shimoda, M., Azegami, H. and Sakurai, T., Traction method approach to optimal shape design problems, SAE 1997 Transactions, Journal of Passenger Cars, Section 6, Vol.106 (1998), pp. 2355 - 2365.

Shimoda, M., Wu, Z. C., Azegami, H. and Sakurai, T., Numerical method for domain optimization problems using a general purpose FEM code (Traction method approach), Transactions of the Japan Society of Mechanical Engineers, Series A, Vol. 60, No. 578 (1994), pp. 250-257 (in Japanese).

Shimoda, M. and Yang, L., A non-parametric free-form optimization method for shell structures, Structural and Multidisciplinary Optimization, Vol. 50 (2014), pp. 409-423.

Sokolowski, J. and Zolesio, J. P., Introduction to shape optimization, shape sensitivity analysis, Springer-Verlag, New York (1991).

Takezawa, A., Nii, S., Kitamura, M. and Kogiso, N., Topology optimization for worst load conditions based on the eigenvalue analysis of an aggregated linear system, Computer Methods in Applied Mechanics and Engineering, Vol. 200 (2011), pp. $2268-2281$.

Wu, Z. C. and Azegami, H., Domain optimization analysis in natural vibration problems (approach using traction method), Transactions of the Japan Society of Mechanical Engineers, Series C, Vol. 61, No. 583 (1995), pp.930-937 (in Japanese).

Wu, Y. T. and Wang, W., Efficient probabilistic design by converting reliability constraints to approximately equivalent deterministic constraints, Journal of Intergrated Design and Process Sciences, Vol. 2, No. 4 (1998), pp. 13 - 21. 